\section{Pengembangan \\ Model Literasi Keluarga}

Berbasis Simplifikasi Cerita Rakyat

Literasi membaca merupakan salah satu kemampuan dasar yang perlu dikuasai, khususnya oleh anak, agar dapat memasuki dan menguasai beragam bidang ilmu. Namun berdasarkan hasil berbagai penelitian dan tes, kemampuan literasi dan aktivitas membaca masyarakat Indonesia masih terbilang kurang. Fenomena tersebut perlu segera diatasi. Berdasarkan hasil studi teoretis dan empiris, literasi keluarga merupakan program yang dapat membantu menumbuhkan dan mengembangkan kemampuan literasi membaca anak. Literasi keluarga merupakan kegiatan literasi yang dilakukan oleh ayah, ibu, anak, dan anggota keluarga lainnya bersama-sama. Literasi keluarga yang dikembangkan di dalam buku ini adalah literasi keluarga berbasis simplifikasi cerita rakyat. Cerita rakyat digunakan sebagai basis dalam literasi keluarga karena cerita rakyat dapat membantu mengembangkan kognitif, bahasa, emosi, sosial, dan moral anak, serta memiliki muatan nilai-nilai positif yang bermanfaat bagi kehidupan anak, yang dapat diimplementasikan dalam kehidupan sehari-hari. Berdasarkan hasil uji coba, model literasi keluarga berbasis simplifikasi cerita rakyat tersebut dapat meningkatkan kemampuan literasi membaca anak dan meningkatkan aktivitas literasi membaca seluruh anggota keluarga.

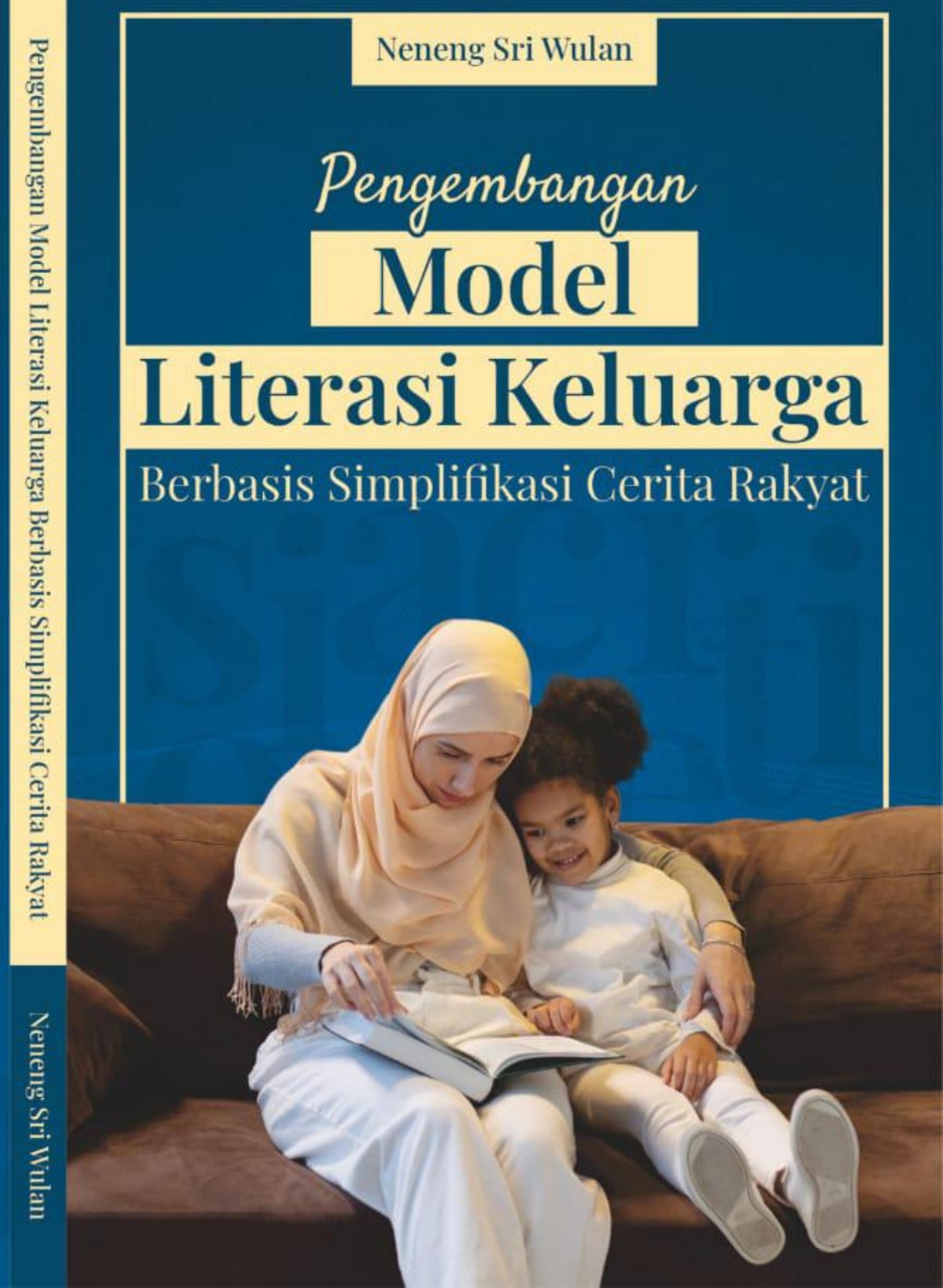


PENGEMBANGAN MODEL LITERASI KELUARGA BERBASIS SIMPLIFIKASI CERITA RAKYAT

NENENG SRI WULAN

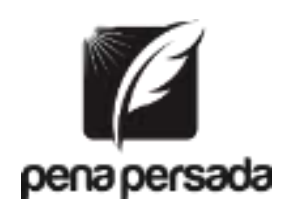

PENERBIT CV. PENA PERSADA 


\title{
PENGEMBANGAN MODEL LITERASI KELUARGA BERBASIS SIMPLIFIKASI CERITA RAKYAT
}

\author{
Penulis: \\ Neneng Sri Wulan \\ ISBN : 978-623-315-671-4
}

Editor:

Tri Hidayati

Design Cover :

Retnani Nur Briliant

Layout :

Dita Nurul Aviqoh

\section{Penerbit CV. Pena Persada}

Redaksi :

Jl. Gerilya No. 292 Purwokerto Selatan, Kab. Banyumas

Jawa Tengah

Email : penerbit.penapersada@gmail.com

Website : penapersada.com Phone : (0281) 7771388

Anggota IKAPI

All right reserved

Cetakan pertama : 2021

Hak Cipta dilindungi oleh undang-undang. Dilarang memperbanyak karya tulis ini dalam bentuk apapun tanpa izin penerbit 


\section{KATA PENGANTAR}

Puji syukur saya panjatkan kepada Tuhan Yang Maha Esa, karena atas berkat dan rahmat-Nya, saya dapat menyelesaikan buku ini. Penulisan buku merupakan buah karya dari pemikiran penulis yang diberi judul " Pengembangan Model Literasi Keluarga Berbasis Simplifikasi Cerita Rakyat". Saya menyadari bahwa tanpa bantuan dan bimbingan dari berbagai pihak sangatlah sulit bagi saya untuk menyelesaikan karya ini. Oleh karena itu, saya mengucapkan banyak terima kasih pada semua pihak yang telah membantu penyusunan buku ini. Sehingga buku ini bisa hadir di hadapan pembaca.

Kajian ini dilatarbelakangi rendahnya kemampuan literasi membaca dan rendahnya aktivitas membaca masyarakat Indonesia. Fenomena tersebut perlu segera diatasi karena literasi membaca merupakan salah satu kemampuan yang dapat membantu seseorang untuk memasuki beragam bidang ilmu. Berdasarkan hasil studi teoretis dan empiris, literasi keluarga merupakan program yang dapat menumbuhkan dan mengembangkan kemampuan literasi membaca anak. Literasi keluarga merupakan kegiatan literasi yang dilakukan oleh ayah, ibu, anak, dan anggota keluarga lainnya.

Kajian dalam buku ini bertujuan bertujuan untuk mengembangkan Model Literasi Keluarga Berbasis Simplifikasi Cerita Rakyat. Proses pengembangan model tersebut mengadaptasi model pengembangan $4 \mathrm{D}$, yang memiliki tahapan define, desgin, develop, dan disseminate. Cerita rakyat yang digunakan sebagai basis dalam literasi keluarga ini memberikan pembelajaran mengenai nilai-nilai positif bagi kehidupan anak, yang dapat diaplikasikan dalam kehidupan sehari-hari. Hasil kajian ini dapat menjadi referensi bagi orang tua, guru, praktisi, dan para pemegang kebijakan terkait, khususnya pada jenjang pendidikan dasar, untuk dapat mengaplikasikan atau bahkan mengembangkan model literasi keluarga sebagai upaya untuk menumbuhkan dan mengambangkan literasi membaca pada keluarga, khususnya pada anak. 
Penulis menyadari bahwa buku ini masih jauh dari kesempurnaan. Oleh karena itu kritik dan saran yang membangun sangat dibutuhkan guna penyempurnaan buku ini. Akhir kata saya berharap Tuhan Yang Maha Esa berkenan membalas segala kebaikan semua pihak yang telah membantu. Semoga buku ini akan membawa manfaat bagi pengembangan ilmu literasi, khususnya literasi keluarga.

Penulis 


\section{DAFTAR ISI}

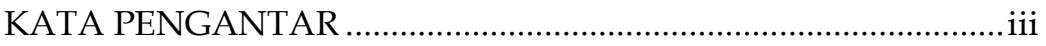

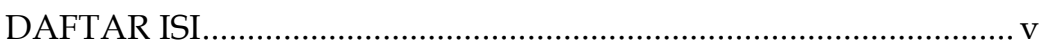

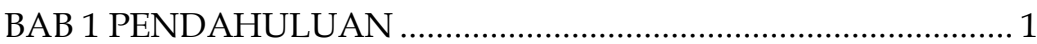

A. Kemampuan Literasi............................................................ 1

B. Gerakan Literasi Nasional................................................. 6

C. Kajian tentang Literasi Keluarga....................................... 9

\section{BAB 2 LITERASI KELUARGA BERBASIS SIMPLIFIKASI}

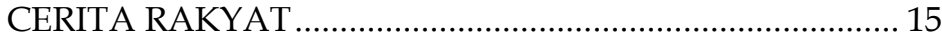

A. Literasi Keluarga ……........................................................ 15

1. Ihwal Literasi Keluarga ................................................. 15

2. model Literasi Keluarga .............................................. 21

B. Kemampuan Literasi dan Kemampuan Literasi

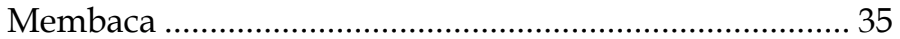

1. Ihwal Kemampuan Literasi........................................... 35

2. Kemampuan Literasi Membaca.................................. 38

C. Ihwal Sastra, Sastra Anak, Cerita Rakyat, Transformasi, dan Simplifikasi Cerita Rakyat.......................................... 41

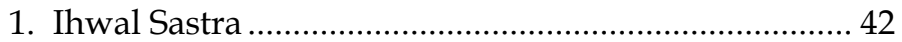

2. Ihwal Sastra Anak.................................................... 45

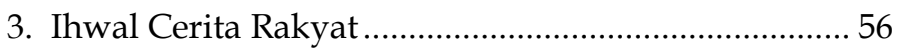

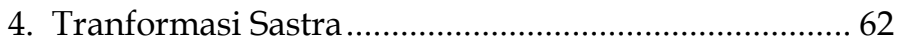

D. Model Literasi Keluarga Berbasis Simplifikasi Cerita

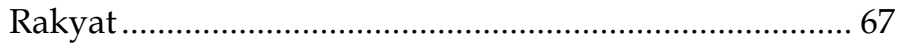

1. Model Literasi Keluarga sebagai Model Pelatihan .... 67

2. Kegiatan Literasi Berbasis Sastra................................. 70

3. Evaluasi dalam Model Literasi Keluarga...................... 74

BAB 3 PROFIL PRAKTIK LILTERASI KELUARGA....................... 79

A. Profil Praktik Literasi Keluarga di Provinsi Jawa Barat.. 79

B. Profil Awal Praktik Literasi Keluarga pada Keluarga di Desa Cigelam........................................................... 90 
BAB 4 ANALISIS SIMPLIFIKASI CERITA RAKYAT

A. Cerita Timun Mas .......................................................... 99

B. Cerita Si Pahit Lidah .......................................................111

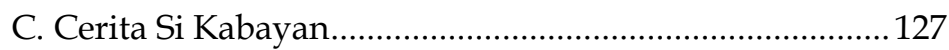

BAB 5 DESAIN HIPOTETIK MODEL LITERASI KELUARGA BERBASIS SIMPLIFIKASI CERITA RAKYAT

A. Unsur-unsur Model Literasi Keluarga Berbasis Simplifikasi Cerita Rakyat

B. Materi dalam Model Literasi Keluarga Berbasis Simplifikasi Cerita Rakyat.

C. Evaluasi Model Literasi Keluarga Berbasis Simplifikasi Cerita Rakyat dan Evaluasi Keterampilan Literasi Membaca Anak

BAB 6 PENGEMBANGAN MODEL LITERASI KELUARGA BERBASIS SIMPLIFIKASI CERITA RAKYAT

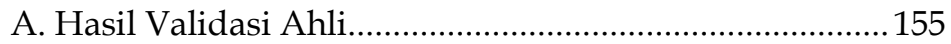

B. Revisi Model Literasi Keluarga Berbasis Simplifikasi Cerita Rakyat. 160

C. Hubungan antara Aktivitas Ayah dengan Kemampuan Literasi Membaca Anak Minggu Ke-1 .... 206

D. Hubungan antara Aktivitas Ayah dengan Kemampuan Literasi Membaca Anak Minggu Ke-2 .... 213

E. Hubungan antara Aktivitas Ibu dengan Kemampuan Literasi Membaca Anak Minggu Ke-2.

F. Hubungan antara Aktivitas Orang tua dan Anak dengan Kemampuan Literasi Membaca Anak Minggu Ke-3.

G. Hubungan antara Aktivitas Ayah dengan

Kemampuan Literasi Membaca Anak Minggu Ke-3 .... 219

I. Hubungan antara Aktivitas Ibu dengan Kemampuan Literasi Membaca Anak Minggu Ke-3. 222

J. Hubungan antara Aktivitas Orang tua dan Anak dengan Kemampuan Literasi Membaca Anak Minggu Ke-3. 
BAB 7 ANALISIS DAN EVALUASI MODEL LITERASI

KELUARGA BERBASIS SIMPLIFIKASI CERITA

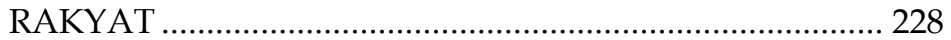

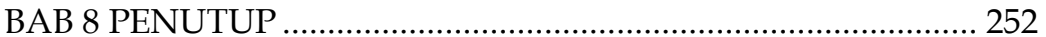

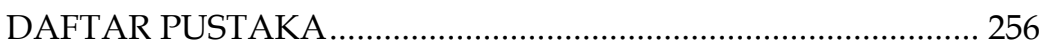

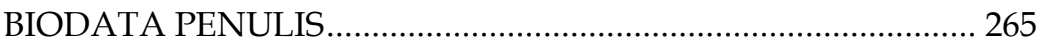




\section{PENGEMBANGAN MODEL LITERASI KELUARGA BERBASIS SIMPLIFIKASI CERITA RAKYAT}




\section{BAB 1 \\ PENDAHULUAN}

\section{A. Kemampuan Literasi}

Literasi merupakan salah satu kemampuan dasar yang harus dimiliki seseorang untuk dapat memperoleh beragam pengetahuan. Dengan memiliki berbagai kompetensi literasi, seperti literasi baca-tulis, literasi finansial, literasi digital, literasi numerasi, dan literasi budaya maka seseorang akan dapat memahami beragam ilmu di era revolusi industri 4.0 ini. Menurut Wasik dan Van Horn (2012), meskipun secara konvensional literasi masih didefinisikan sebagai kemampuan membaca dan menulis, namun makna literasi telah berkembang mencakup seperangkat keterampilan kompleks dan multidimensi, yang dimulai saat seseorang lahir dan berkembang selama hidupnya.

Menurut UNESCO, literasi merupakan hak asasi manusia, alat untuk memberdayakan diri dan sarana untuk membangun manusia dan lingkungan sosialnya. Kesempatan untuk mengembangkan pendidikan bergantung pada kemampuan literasi. Literasi adalah inti atau dasar dari pendidikan untuk semua orang (Wasik, 2012). Kemampuan literasi merupakan kemampuan penting untuk dikuasai agar dapat memenuhi kebutuhan dasar manusia, menjalankan fungsi sebagai individu dan sebagai makhluk sosial, mengakses pengetahuan, mengekspresikan gagasan, dan mengembangkan potensi diri.

Kemampuan literasi dibutuhkan untuk dapat mengakses beragam informasi. Negara dengan masyarakat yang memiliki kemampuan literasi yang tinggi cenderung akan lebih berkembang atau bahkan lebih maju dibandingkan dengan negara yang tingkat literasinya rendah. Berdasarkan hal tersebut, literasi tidak lagi dipahami sebagai perubahan individu saja, namun juga perubahan sosial. Dengan memiliki kemampuan literasi yang baik, seseorang dapat menjalani 
kehidupannya dengan lebih baik dan berkualitas (Kemendikbud, 2017a).

Berdasarkan pemaparan sebelumnya, dapat dikatakan bahwa kemampuan literasi merupakan kemampuan penting yang harus dikuasai seseorang. Pentingnya kemampuan literasi tersebut ternyata bertolak belakang dengan fenomena kemampuan literasi masyarakat Indonesia saat ini. Kemampuan literasi masyarakat Indonesia saat ini masih berada dalam kategori rendah. Berdasarkan penelitian UNESCO pada 2012, literasi membaca orang Indonesia baru mencapai 0,001. Hal tersebut berarti bahwa dari 1000 orang Indonesia, hanya 1 orang yang melakukan kegiatan membaca serius. Selain hal tersebut, hasil tes Programme for International Student Assessment (PISA) pada 2012 pun tidak jauh berbeda. Tes ini dilakukan terhadap siswa berusia 15 tahun, mengenai literasi membaca, sains, dan matematika. Indonesia berada di urutan 64 dari 65 negara. Skor literasi membaca siswa Indonesia sebesar 396, berada di bawah skor rata-rata sebesar 496. Hasil tes PIRLS (Progress International Reading Literacy Study) yang mengevaluasi kemampuan membaca anak kelas IV pun tidak jauh berbeda (Antoro, 2017).

Berdasarkan laporan PIRLS 2011, kemampuan tertinggi membaca siswa kelas 4 adalah siswa Singapura dengan kategori level sempurna mencapai $24 \%$. Urutan berikutnya adalah Rusia, Irlandia Utara, Finlandia, Inggris, Hongkong, dan Irlandia dengan capaian antara $15-19 \%$ mampu menjawab pada level sempurna. Di level sedang dicapai oleh siswa Perancis, Austria, Spanyol, Belgia, dan Norwegia dengan persentase $70 \%$. Median level sempurna mencapai $8 \%$, tinggi $44 \%$, sedang $80 \%$, dan lemah 9\%. Sementara itu, siswa Indonesia mampu menjawab butir soal level sempurna sebanyak $0,1 \%$, mampu menjawab butir soal level tinggi $4 \%$, mampu menjawab butir soal level sedang $28 \%$, dan mampu menjawab butir soal level lemah $66 \%$. Hal tersebut berarti bahwa siswa Indonesia di level sempurna, tinggi, dan sedang berada di bawah persentase median yang dicapai oleh siswa secara internasional, sementara 
di level lemah berada di atas median siswa internasional (Suryaman, 2015: 172).

Hal tersebut pun tidak jauh berbeda dengan nilai Asesmen Kompetensi Siswa Indonesia (AKSI)/Indonesia National Assessment Programme (INAP). Program ini dilakukan oleh Puspendik Kemendikbud pada tahun 2016 untuk menguji kemampuan membaca, sains, dan matematika bagi siswa sekolah dasar kelas IV. Hasilnya menunjukkan bahwa pada kemampuan membaca, sebanyak $46,83 \%$ anak berada pada kategori kurang, sebanyak 47,11\% dalam kategori cukup, dan $6,06 \%$ siswa berada dalam kategori baik (Satgas Gerakan Literasi Sekolah, 2019).

Menurut Stern \& Nordstrum, hasil tes EGRA (Early Grade Reading Assesment) pada 4.812 anak yang duduk di kelas 2 sekolah dasar menunjukkan bahwa kurang dari 50\% anak mampu membaca dan memahami isi bacaan. Sebanyak 5,8\% anak tidak dapat membaca sama sekali (Mulyati, 2019). Bila hal tersebut dikaitkan dengan cara guru melakukan pembelajaran, USAID menarik kesimpulan bahwa hanya 17,9\% guru yang telah melakukan pembelajaran membaca dengan efektif (USAID PRIORITAS dalam Mulyati, 2019).

Permasalahan literasi membaca juga dikaji oleh Pusat Penelitian Pendidikan dan Kebudayaan Kemendikbud (2019), yang melakukan riset mengenai Indeks Alibaca atau Indeks Aktivitas Literasi Membaca secara nasional. Berikut ini adalah grafik hasil penelitian tersebut. 


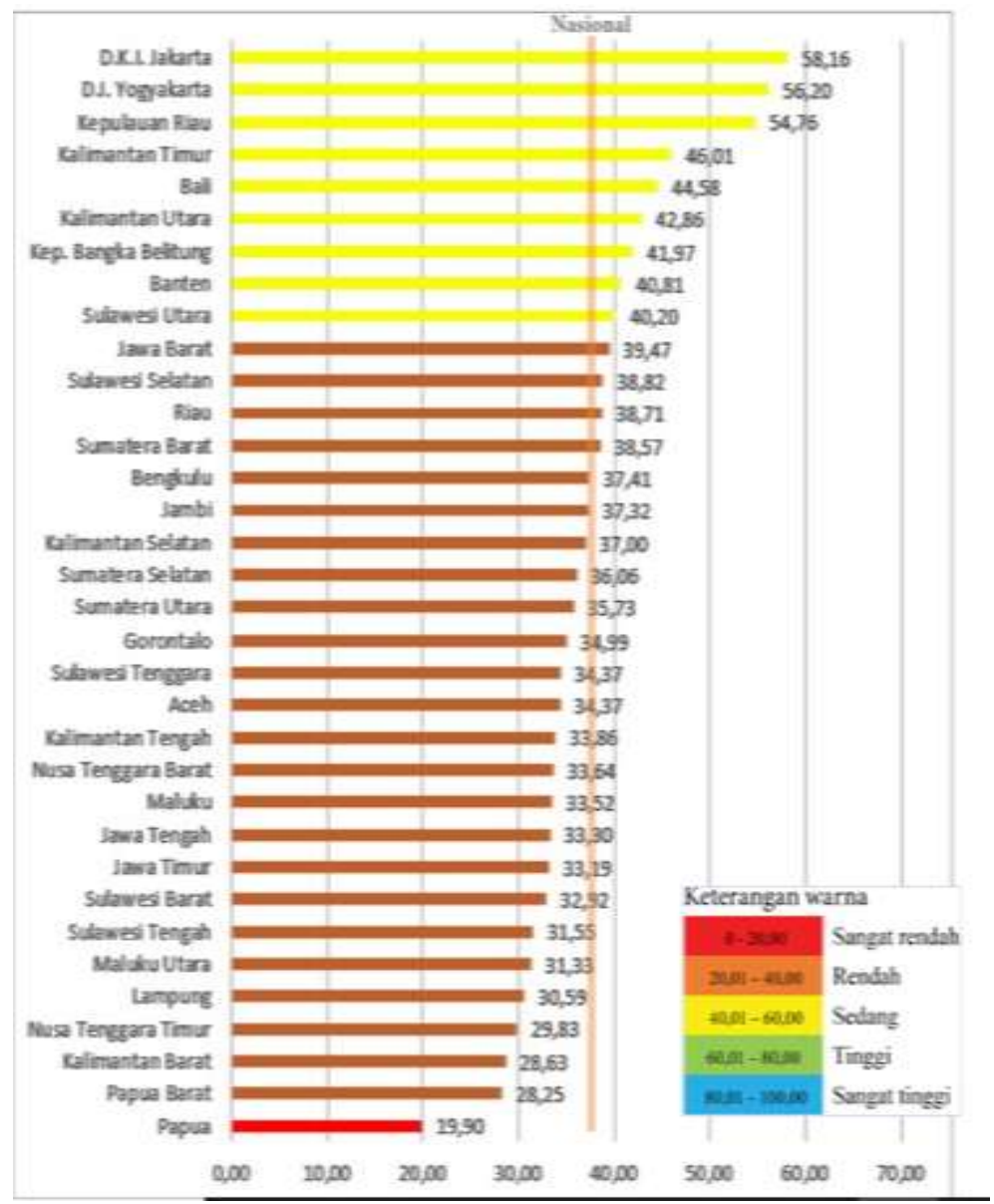

Grafik 1.1

Indeks Aktivitas Literasi Membaca 34 Provinsi

Sumber: Indeks Aktivitas Literasi Membaca 34 Provinsi, Puslitjakdikbud, 2019

Pengukuran Aktivitas Literasi Membaca tersebut berdasarkan dimensi kecakapan, dimensi alternatif, dimensi budaya, dan dimensi akses. Secara nasional, semua dimensi tersebut berada pada kategori rendah dan sangat rendah, kecuali dimensi kecakapan yang berkategori tinggi. Berdasarkan grafik 1.1 dapat dilihat bahwa indeks aktivitas 
literasi membaca nasional masuk dalam kategori literasi rendah. Hasil riset tersebut menunjukkan 9 provinsi berkategori sedang, 24 provinsi berkategori rendah, dan 1 provinsi berada pada kategori sangat rendah. Hal tersebut berarti bahwa baik secara nasional maupun regional, indeks aktivitas literasi membaca masyarakat kita tidak berada pada kategori tinggi. Indeks tinggi diraih oleh DKI Jakarta, D.I. Yogyakarta di posisi kedua, dan Kepulauan Riau di posisi selanjutnya. Indeks terendah terendah, yaitu Papua, Papua Barat, dan Kalimantan Barat.

Pemaparan mengenai hasil tes PISA, PIRL, dan EGRA menunjukkan bahwa terdapat permasalahan dalam kemampuan literasi membaca di Indonesia. Pemaparan mengenai hasil penelitian indeks alibaca menunjukkan bahwa terdapat persalaman dalam aktivitas literasi masyarakat Indonesia. Untuk mengatasi permasalahan-permasalahan tersebut, pemerintah telah melakukan berbagai upaya. Salah satu upaya tersebut adalah menurunkan tingkat buta aksara dan meningkatkan tingkat melek huruf masyarakat Indonesia. Sensus Badan Pusat Statistik (BPS) tahun 2015 menunjukkan bahwa jumlah penduduk Indonesia yang buta aksara sebanyak 5.629.943 orang atau tinggal 3,49\% dari keseluruhan. Berdasarkan data BPS dan PDSPK pada 2015, masyarakat Indonesia yang berusia 15-59 tahun memiliki tingkat melek huruf sebesar sebesar 96,51\%. Upaya tersebut telah menampakkan hasil dan kini pemerintah berusaha untuk meningkatkan kemampuan literasi dan minat baca masyarakat dengan berbagai upaya. Salah satu upaya yang dilakukan untuk meningkatkan kemampuan literasi adalah dengan mencanangkan Gerakan Literasi Nasional (GLN). GLN mencakup gerakan literasi keluarga, sekolah, dan masyarakat. Gerakan-gerakan tersebut berupaya untuk menyinergikan seluruh potensi dan memperluas partisipasi publik dalam menumbuhkan, mengembangkan, dan membudayakan literasi di Indonesia secara masif, baik dalam ranah keluarga, sekolah, 
maupun masyarakat di seluruh Indonesia (Kemdikbud, Panduan Gerakan Literasi Nasional, 2017).

Gerakan literasi tersebut merupakan salah satu upaya untuk mengembangkan kecapakan hidup masyarakat. Pemerintah bisa saja menyerahkan pengembangan gerakan literasi tersebut kepada masyarakat, namun lebih memilih untuk mengembangkannya sendiri. Hal tersebut seperti yang dilakukan oleh beberapa negara, yaitu Kanada yang telah memulai gerakan literasi sekolah mulai tahun 2007 dan Swiss yang telah memulainya sejak menjadi peserta PISA tahun 2000 (Heryani, 2020).

\section{B. Gerakan Literasi Nasional}

Gerakan Literasi Nasional yang memuat Gerakan Literasi Sekolah, Literasi Keluarga, dan Literasi Masyarakat mulai dilakukan dan dibudayakan dalam kegiatan sehari-hari. Meskipun ketiga gerakan tersebut dicanangkan secara bersamaan, namun keberadaan program literasi keluarga tidak sepopuler gerakan literasi sekolah. Gerakan literasi keluarga masih belum akrab di kalangan masyarakat dan implementasinya pun masih terbatas. Hal tersebut dapat menjadi kendala dalam mewujudkan tujuan besar gerakan literasi, karena literasi keluarga merupakan kegiatan literasi awal yang dilakukan oleh seseorang. Lingkungan keluarga merupakan lingkungan pertama seseorang yang dapat mengenalkannya pada kegiatan literasi. Literasi keluarga yang dimaksud di sini adalah kegiatan literasi yang dilakukan oleh orang tua dan anak, baik di rumah maupun di komunitas. Literasi keluarga dilakukan pada kegiatan keseharian (Decoda, 2010). Sehubungan dengan gerakan literasi keluarga, sebenarnya pemerintah telah meluncurkan dan mengimplementasikan bererapa program edukasi untuk keluarga, salah satunya yaitu Program Pendidikan Masyarakat. Menurut Direktorat Pembinaan dan Pendidikan Keluarga (2015), program ini diharapkan dapat berperan dalam menjalin kemitraan antara satuan pendidikan dan orang tua dalam mengembangkan pendidikan anak. Dengan program ini, 
keluarga, sekolah, dan masyarakat diharapkan dapat bekerja sama untuk melakukan pembiasan positif, mulai dari jenjang pendidikan paling rendah hingga tinggi, baik pendidikan formal maupun nonformal. Dimensi pada kurikulum pendidikan keluarga adalah pembinaan orang tua, hubungan orang tua dan anak, pertumbuhan dan perkembangan anak, pembinaan keluarga, masyarakat dan budaya. Berdasarkan pemaparan tersebut, gerakan literasi keluarga secara implisit telah terdapat di dalam program tersebut, namun tidak mendalam atau mendetail mengenai implementasinya. Hal tersebut karena program pendidikan keluarga lebih terfokus pada kegiatan edukasi terhadap keluarga agar berperan aktif dalam pendidikan anak sehingga terjadi sinergi antara sekolah dan keluarga.

Program lain yang berhubungan dengan edukasi keluarga juga dibuat oleh kemendikbud, yaitu Gerakan Nasional Orang Tua Membacakan Buku (Gernas Baku). Gernas Baku adalah gerakan nasional kerja sama pemerintah dan pegiat PAUD, perguruan tinggi, dan dunia usaha untuk menumbuhkan budaya baca. Tujuan program ini adalah untuk membiasakan orang tua membacakan buku kepada anak, mempererat hubungan sosial emosi antara orang tua dan anak, menumbuhkan minat baca anak sejak usia dini (Kemendikbud, 2018). Pada program tersebut telah disebutkan teknis pelaksanaan pembacaan buku terhadap anak. Implementasi program tersebut adalah sebagai berikut 1) orang tua belajar memahami kemampuan baca anak (sesuai tahap perkembangan), 2) orang tua belajar memahami teknik menarik minat anak untuk membaca, 3) orang tua belajar memahami teknik membacakan buku sesuai tahap perkembangan anak, 4) orang tua belajar membiasakan untuk membacakan bacaan atau bercerita kepada anak (Kemendikbud, 2018). Dari pemaparan tersebut, dapat dikatakan bahwa program tersebut merupakan salah satu realisasi kegaitan literasi keluarga. Namun karena program tersebut merupakan program yang dibidik untuk PAUD, sehingga implementasinya masih 
terbatas pada keluarga-keluarga yang memiliki anak usia dini. Implementasi program tersebut pun melibatkan peran lembaga PAUD, keluarga, dan masyarakat. Program tersebut pun masih terfokus pada kegiatan membaca saja. Hal tersebut menunjukkan bahwa pemahaman terhadap kemampuan literasi masih terbatas pada kemampuan membaca saja. Hal tersebut bertolak belakang dengan konsep literasi yang dipaparkan oleh para ahli. Menurut Heryani (2020), selain berhubungan dengan kemampuan membaca, menulis, menyimak, dan berbicara, literasi adalah kemampuan yang memiliki fungsi untuk menyatukan pengetahuan, kemampuan, keterampilan, dan sikap. Literasi merupakan kompetensi yang dapat membuat seseorang mampu berpikir kritis, berkomunikasi dengan baik, dan mengatasi masalah hidup.

Program-progam edukasi yang telah dipaparkan sebelumnya sebenarnya telah dirancang dengan baik, karena pada dasarnya keterlibatan keluarga merupakan aspek penting dalam proses mengembangkan berbagai kemampuan anak, khususnya kemampuan literasi anak. Pengembangan kemampuan literasi melalui pembudayaan kegiatan literasi memang idealnya dilakukan sejak masa kanak-kanak. Pada usia kanak-kanak, pembiasaan yang positif dapat lebih mudah ditiru atau diserap oleh anak, sehingga hasilnya dapat lebih optimal. Keluarga sebagai sekolah awal bagi anak, merupakan aspek potensial untuk melakukan pembiasaan tersebut. Namun berdasarkan pemaparan sebelumnya, baik Program Pendidikan Masyarakat maupun Gernas Baku, belum dapat memberikan gambaran secara mendetail mengenai kegiatan literasi keluarga. Belum ada model literasi keluarga yang dapat memberikan wawasan dan gambaran secara mendetail mengenai praktik literasi keluarga yang dapat diaplikasikan oleh seluruh keluarga yang memiliki anak, baik yang berada di jenjang pendidikan anak usia dini maupun sekolah dasar. Oleh karena itu, dibutuhkan sebuah model literasi keluarga yang dapat mengakomodasi hal-hal tersebut. Model literasi keluarga tersebut harus dapat melibatkan seluruh anggota keluarga 
dalam mengaplikasikan kegiatan literasi dan model tersebut diharapkan dapat mengembangkan kemampuan literasi anak, khususnya literasi membaca.

\section{Kajian tentang Literasi Keluarga}

Penulis bermaksud untuk mengembangkan model literasi keluarga karena berdasarkan hasil berbagai penelitian menunjukkan bahwa literasi keluarga dapat mengembangkan kemampuan literasi anak dan membuat anak lebih berhasil di sekolah (Chao et al, 2015; Swick, 2009). Pendidikan literasi perlu dimulai dari lingkungan keluarga. Berbagai kegiatan di dalam keluarga dapat membangun kebiasaan berliterasi, seperti pemodelan pada aktivitas membaca keluarga, penyediaan bahan membaca, kunjungan ke pameran atau toko buku, pembiasaan membacakan cerita sebelum tidur, dan aktivitas lainnya. Kualitas literasi keluarga yang baik dapat berdampak positif terhadap kemampuan literasi awal anak dan dapat menjadi dasar yang baik bagi pemerolehan kemampuan literasi berikutnya (Mulyati, 2019).

Berdasarkan hasil penelitian Chao et al, program literasi keluarga dapat meningkatkan aktivitas literasi di dalam keluarga dan kosakata anak. Penelitian tersebut memaparkan bahwa interaksi orang tua dan anak ketika membaca bersama menjadi meningkat, keluarga menjadi memiliki rutinitas membaca buku bersama anak, akses terhadap bacaan menjadi tersedia, kunjungan ke perpustakaan menjadi lebih sering, keluarga menjadi memiliki kemauan untuk mempelajari literasi dini, dan perbendaharaan kosakata yang dimiliki anak pun menjadi bertambah (Chao et al, 2015). Selaras dengan penelitian tersebut, Parry et al juga memaparkan hasil penelitiannya bahwa program literasi keluarga dapat mengembangkan keterampilan literasi anak (Kate Parry, Elizabeth Kirabo, and Gorreth Nakyato, 2014). Rabkin et al (2018) juga memaparkan di dalam hasil penelitiannya bahwa 1) dengan mengikuti program literasi keluarga, orang tua lebih terlibat dalam proses pembelajaran anaknya di sekolah, 2) proses belajar-mengajar menjadi lebih berkualitas, 3) kemampuan literasi siswa menjadi 
lebih berkembang (Gabriele Rabkin, Stefanie Geffers, Ulrike Hanemann, Meike Heckt, Marcus Pietsch, 2018).

Penelitian-penelitian tersebut menunjukkan bahwa literasi keluarga memberikan pengaruh yang positif terhadap kemampuan literasi anak dan budaya baca di dalam keluarga. Selain penelitian tersebut, peneliti pun telah melakukan penelitian awal yang serupa mengenai literasi keluarga (Wulan \& Sundari, 2017). Program literasi keluarga memberikan pengaruh yang cukup baik terhadap kemampuan literasi dini anak dan persepsi anak terhadap kegiatan tersebut pun positif. Penelitian tersebut dilakukan di kota Serang dengan subjek penelitian sebanyak 36 siswa. Pada penelitian tersebut, model literasi keluarga yang diaplikasikan sesuai dengan pendapat dari the National Adult Literacy Agency (NALA). Kegiatan literasi keluarga menurut (NALA, 2010) adalah kegiatan lisan dan visual, numerasi, membaca dan menulis, praktik teknologi terbaru, dan kegiatan hiburan.

Meskipun penelitian tersebut menunjukkan hasil yang positif, namun terdapat beberapa permasalahan yang muncul pada saat pelaksanaan kegiatan literasi keluarga tersebut. Permasalahan tersebut yaitu, 1) pengetahuan dan kemampuan orang tua dalam kegiatan literasi keluarga, 2) peran orang tua dalam kegiatan literasi keluarga, 3) intensitas kegiatan orang tua dan anak, 4) peran guru/instruktur pada kegiatan literasi keluarga, 5) peran komunitas dalam kegiatan literasi keluarga, 6) kondisi ekonomi keluarga.

Permasalahan pertama, yaitu pengetahuan dan kemampuan orang tua dan kegiatan literasi keluarga cukup beragam. Berdasarkan hasil observasi dan wawancara tidak semua orang tua memahami dan memiliki kompetensi untuk membimbing anaknya dalam kegiatan literasi keluarga. Sebagai contoh hal tersebut adalah 1) ada orang tua yang dapat membacakan cerita dengan baik untuk anaknya dan dapat membimbing anaknya untuk belajar membaca karena memiliki anggapan bahwa kegaitan literasi keluarga itu penting untuk menunjang kemampuan literasi anaknya, 2) ada orang tua yang 
hanya membacakan cerita untuk anaknya namun tidak memahami sepenuhnya manfaat dari kegiatan tersebut, 3) ada orang tua yang memiliki anggapan bahwa kemampuan literasi anak dapat diperoleh dengan maksimal di sekolah bukan di rumah.

Permasalahan yang kedua, yaitu peran para orang tua dalam kegiatan literasi keluarga tidak sama. Berdasarkan hasil penelitian, terdapat orang tua yang berperang aktif dalam kegiatan literasi keluarga. Orang tua tersebut menjadi fasilitator kegiatan literasi anak di rumah. Orang tua terlibat aktif dalam pelajaran anaknya (tugas sekolah), menjadi sumber literasi di rumah (pembaca cerita, menyediakan waktu untuk diskusi, dll), dan melakukan diskusi dengan guru/ instruktur tentang kemampuan literasi anaknya. Ada pula orang tua yang hanya melakukan satu atau dua peran dari pada orang tua yang terlibat aktif.

Permasalahan yang ketiga, yaitu intensitas kegiatan orang tua dan anak. Permasalahan ini muncul karena waktu kebersamaan para orang tua dan anak yang cukup beragam. Anak yang memiliki ayah dan ibu pekerja tentu memiliki waktu kebersamaan yang lebih sedikit dibandingkan dengan anak yang salah satu orang tuanya bekerja atau kedua orang tuanya bekerja di rumah (wiraswasta).

Permasalahan yang keempat, yaitu peran guru/ fasilitator literasi keluarga. Pada penelitian sebelumnya, guru atau fasilitator tidak dilibatkan dalam kegiatan literasi keluarga tersebut. Guru hanya sebagai penghubung antara fasilitator dengan keluarga. Hal tersebut menjadi permasalahan ketika terdapat orang tua yang memiliki pertanyaan mengenai kegiatan literasi keluarga atau ingin melakukan diskusi mengenai literasi keluarga atau kemampuan literasi anaknya. Orang tua tidak melakukan diskusi dengan guru karena merasa kegiatan tersebut berada di luar kewenangan guru/ sekolah. Orang tua pun memiliki keseganan untuk melakukan diskusi dengan fasilitator/instruktur karena merasa tidak memiliki 